\title{
A Study of Climate Adaptation of Hue Traditional Garden House in Vietnam and the Application in Contemporary House
}

\author{
Le Ngoc Van Anh and Fausto Pugnaloni
}

\begin{abstract}
The aim of this study is introduction about Hue traditional garden house (HTGH), which is a product of past life style, and analysis about the climate adaptive elements of it to indicate the advantages and disadvantages of traditional construction methods. The object research is Kim Long village where concentrate many HTGH. This study bases on over forty drawings of HTGH in Kim Long area, field survey, oral history, and literature. From the result of this research, it proves the existence of HTGH until now is an evidence about benefits of using the natural energy, local climate. Therefore, studying the way to build the traditional housing is one of the significant methods need to be studying and maintain in the modern construction.
\end{abstract}

Index Terms-Hue traditional garden house, climate adaption, contemporary house.

\section{INTRODUCTION}

Located at the centre of Vietnam, Hue city was the capital of Nguyen Dynasty (1802-1945), the last dynasty of Vietnam. In this period, while Nguyen Kings lived in the Purple Forbidden City, other members of royal family and high-ranking mandarins lived in HTGH. They are wooden house located in large area with vegetation surround. HTGH is not only the dwelling house but also valuable symbol in cultural heritage of Hue. However, they are demolished dramatically under the speed development of urbanism. Nowadays, construction has trend of glass and concrete using without responding climate, housing is just a machine cost many energy. Architecture is a part of natural so that building must adaptive environment where they exist is an important mission. HTGH has existed for a long time is an evidence of adaptation to local environment.

Kim Long village is case study area in this research. It is located beside the Huong River (Fig.1a), with over 40 houses (Fig.1b). Recently, a large number of HTGHs have been severely demolished and converted into various configurations to adaptive with contemporary life but most of the HTGH in Kim Long have been conserved and preserved by government and other concerned organizations for tourism. Therefore, HTGH in Kim Long village are chosen representative objects of study.

Hue is a city with hot humid climate with summer form

Manuscript received June 20, 2012; revised November 15, 2012

The authors are with the Department of Construction Civil Engineering and Architecture, Faculty of Engineering, Polytechnic University of Marche, via Brecce Bianche 1, 60131 Ancona, Italy (e-mail: vananh.kts@gmail.com; f.pugnaloni@univpm.it).
May to September and winter from October to April next year with many disadvantage such as heavy rainfall during winter, include storm, flood and high temperature, high moisture in summer. Therefore, the most important for housing design in this area are ventilation and radiation reduction by shading, insulation, surrounding vegetation. In addition, the site selection, orientation, material using is necessary attention. The adaptation of HTGH can be analysis with three following part: layout, structure, and material.

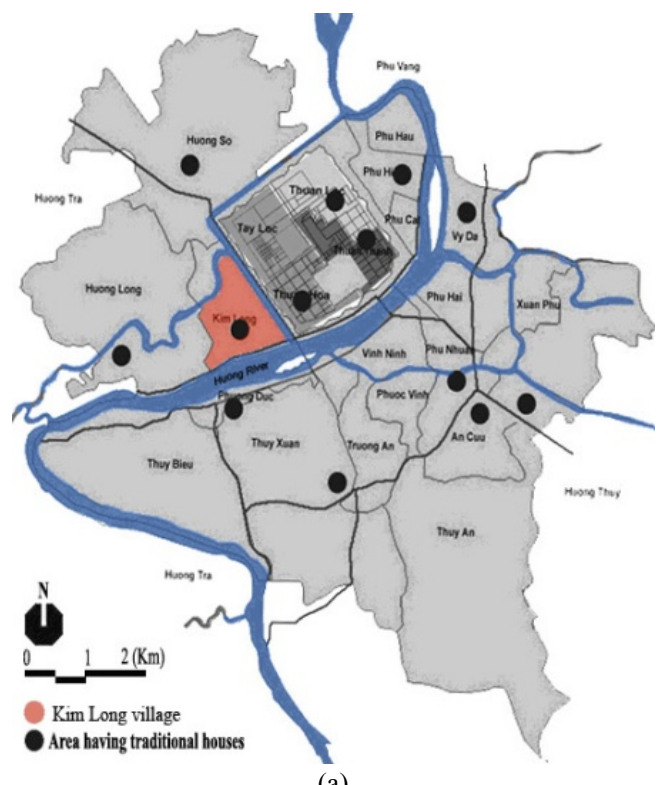

(a)

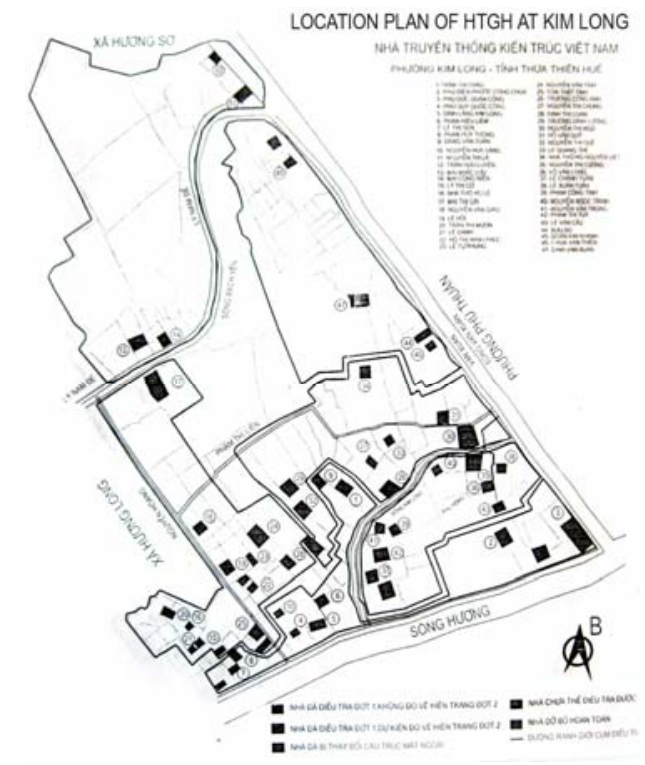

(b)

Fig. 1. (a)Map of distribution HTGH in Hue city (b) Location plan of HTGH at Kim Long 


\section{LAYOUT}

\section{A. Site Selection and Orientation}

In hot-humid area, air movement constitutes the main comfort-restoring element. Site offset from the prevailing wind direction, but exposed to high air-stream areas near the crest of a hill, or high elevations on the windward side near a ridge, are preferable [1]. Thus, Hue is located on Southeast Asian monsoon area, which is controlled by two main winds: summer wind and winter wind, the direction changes follow season. In winter (from October to April next year), the prevailing wind direction is Northwest (frequency $25 \%-29 \%$ ). In summer (from May to September), the prevailing wind direction is south (frequency $12 \%-16 \%$ ) wind and foehn Southwest (11\%-16\%) [2]. With this condition, Kim Long is located in an advantaged location with Huong River stays in the south. In summer, the wind flows from the south cool the site. Moreover, southwest wind is a hot dry; humidity sometime is down to $30 \%$ and temperature up to 43 degree. Thanks to water in the south, wind carries moisture into the site make hot air reduces. During the day, land temperature is higher than water body. Cool air by evaporation from river moves over the land to replace hot air. In contrast, convective line is formation and moved back at night because the land temperature heat down.

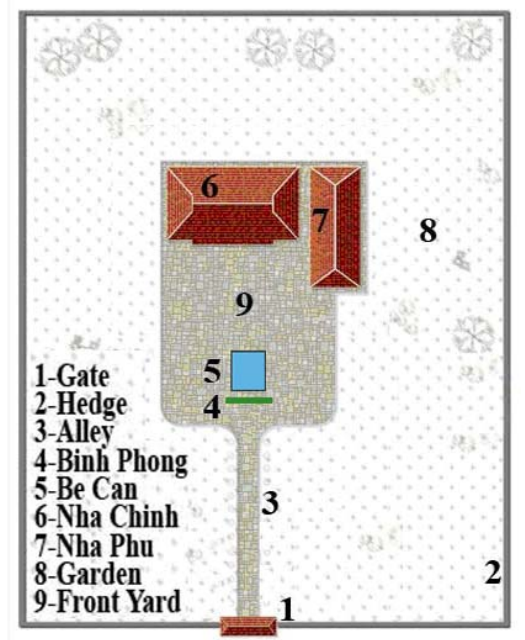

Fig. 2. Site plan of HTGH

Each HTGH have a large area, from 500-2000m2, HTGH layout include the following elements: gate, hedge, small alley, binh phong (screen), be can (basin), nha chinh (main house), nha phu (out house), front yard and garden (Fig. 2). Most of all activities happen in main house; out house is a space of kitchen and toilet, then, mainly orientation focus on the design of main house. Following the conclusion of Felix Marboutin about making calculation on sun intensities [3]:

1. For best living conditions (warmth in winter, coolness in summer) principle façades of buildings should face south. 2 . Facades facing southeast and southwest offer the advantage of regularity of isolation, but they are colder in winter and warmer in summer than façade facing south. 3. East and west exposures are warmer in summer and colder in winter than are south, southeast, and southwest exposures. Thus, the survey forty drawings of HTGH in Kim Long [4] indicate that the main orientation of main house is North-South, Northeast-Southwest, and Northwest-Southeast with front façade. It does not have any house orientation of West -East. This is an optimum orientation for the house.

\section{B. Green Space and Other Surrounding Elements}

Main house and outhouse are covered by surrounding green space. They are gate, hedge, screen, and garden. Firstly, with $500-2000 \mathrm{~m} 2$ of total area, the garden occupies most of area. It is the multi-category features and multi-canopied. In summer, the surface of grass and leaves absorb radiation, and their evaporation process can cool air temperatures. Above all, they provide generous shade at the right seasons [5]. Especially, big tree is planted in the side of west and east wall with density radiation. The microclimate created by vegetation produces transpiration and shade that can potentially provide an estimate 3 to 5 degrees $\mathrm{C}$ cooling benefit [6]. Besides, from September to January, Hue has high rainfall with storm wind. Plants can reduce wind velocity, control the wind direction, and avoid the impact of storm to the house.

The shape of tree shadow is one of shading device, therefore, the choice type of plants is very important to create shades adapt to each season or each time of day. In folk, the idiom "truoc cau sau chuoi" mean that, in front of the house, plant areca palm tree, in back plant the banana tree. Thus, most of HTGHs have north-south orientation, front façade face south. Areca palm tree has small shape and high, planting in front would not prevent morning sun. At noon, with high-altitude sun, the shading of areca palm tree would cover veranda. In addition, the high and small body of this tree is an advantage condition for catching the cool south wind. On the contrary, banana is adjacent tree with big leaf. Large shadow would prevent the intense sunlight in the afternoon. In winter, the big leaf could block the cold wind from the north. Besides, garden is surrounded by green hedge. This shrubs fence separates the house with neighboring without masonry.

Secondly, screen and basin also support for ventilation. Screen is a row shrubs in front of the main house, is trimmed like a green wall to control wind direction. Basin is a small shallow tank, located behind screen. When the wind blows through basin would bring air cool by evaporate into the house (Fig. 3). Small alley is limited by two parallel shrubs hedge, connect the gate and house. The airflow and wind velocity is also controlled or modified markedly thanks to alley. Besides that, the multi-canopied plant creates pressure differences is a good condition for ventilation.

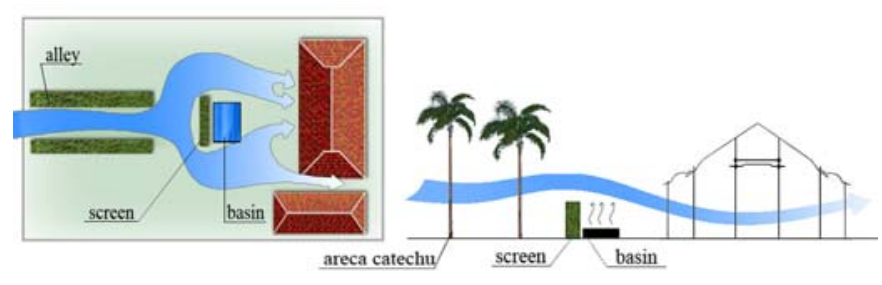

Fig. 3. The effect of catching the breeze under impact of alley, screen, and basin

\section{The Structure Compositions of Main House}

The Timber Structure: The main house is created by the timber-framed system. The system connects together by itself with beams though without screws using. Main house use keo structure style, a design method in central of Vietnam [7] (Fig. 
4). The space between to keo structure (in this paper: a structure module) is Gian. Nha Chinh usually has from one to five gian. The house has the more gian the longer. The form of house varies with the region and the effects of thermal forces may be expressed in architectural terms, within the "limit of elasticity". In hot humid region, the sun attacks the east and west ends of house and forces it into a slender elongated structure. Therefore, the building freely longed in the east west direction is advantageous. Building located on the north-south axis receive greater penalty than they would in other climate zones. Hence, it is obvious that the form of main house can expand to length of space by building more the same keo structures. It means the length dimension is customizable. One more gian would be addition when building one more keo structure. In addition, as I mention before, most of main house in Kim Long area located on the west east, northwest southeast and northeast southwest axis. Therefore, this is an effective choice of HTGHs for against the sun from West and East (Fig.5).

The columns are long from $2 \mathrm{~m}$ to $2.5 \mathrm{~m}$, which is an important characteristic for storm protection, hurricane easily. Properly constructed timber building will withstand the pressure of storm winds. All of the timber columns put on the stones cube or cylinder. In Hue city, rainy season is from September to January with many floods. Staying under water for all the flood day, the timber would be decayed. Thus, the purpose of the stone system is withstand flood, without stone, timber columns would be exposure to water last from one day to one week of flood. It is the condition for mechanical breakdown. In addition, from traditional house before, the columns were buried in the ground. With humid and flood climate, it is the condition for attraction of insect and fungus. The ancients had creative to put all systems on stone for protection against termites and dampness.

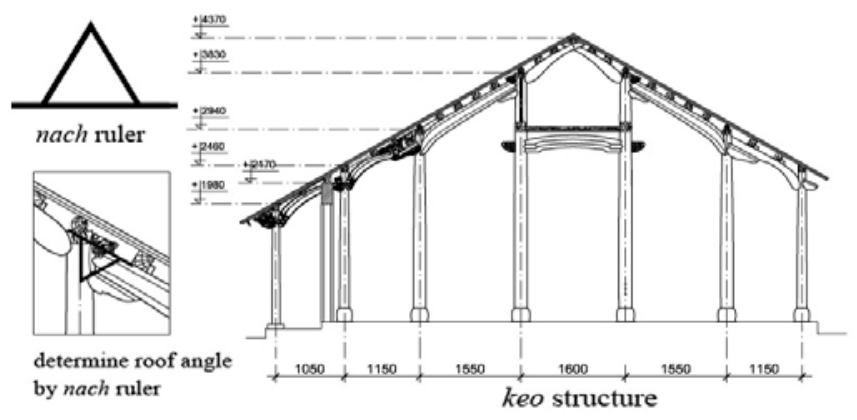

Fig. 4. nach ruler and keo structure

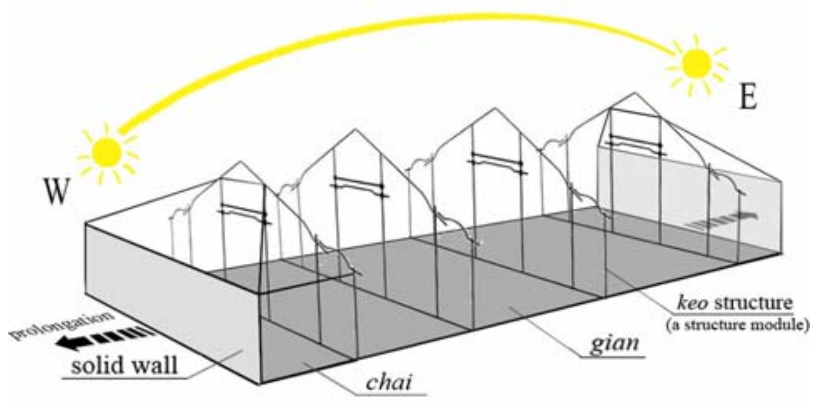

Fig. 5. The prolongation of house follows east-west

The Roof: Main house use the pitched roofs, which is necessary for the disposal water and effective in control of solar radiation. In fact, the roof of main house includes two parts: front roof and back roof. If main house have chai, would be have two other roofs of two sides. Following the traditional building under Nguyen dynasty, Nach ruler, the shape of equilateral triangle with each edge is a $400 \mathrm{~mm}$, the carpenters use this tool to determine the slope of roofs. Therefore, the steep angle is always 30 degree which consistent with the extreme rainfall of Hue city and drainage quickly. Besides that, southern and northern slope direction is more desirable because east and west sides receive more radiation than other orientations where the sunrays come in a more oblique angle.

Roof is one of the important elements of all building; it has the greatest effect on thermal comfort of building because it is often the leading source of heat intrusion by receiving solar radiation directly. Thus, the traditional roof has many layers. The thickness of the roof is about $10 \mathrm{~cm}$. It is such as an insulation panel to separate the interior and exterior. Roof usually has three layers of liet title, yin-yang roof title, or thatch. Beside of insulation function, the purpose of thick roof fixes the timber-framed system into the ground and withstands the pressure of storm winds. (Fig.6)

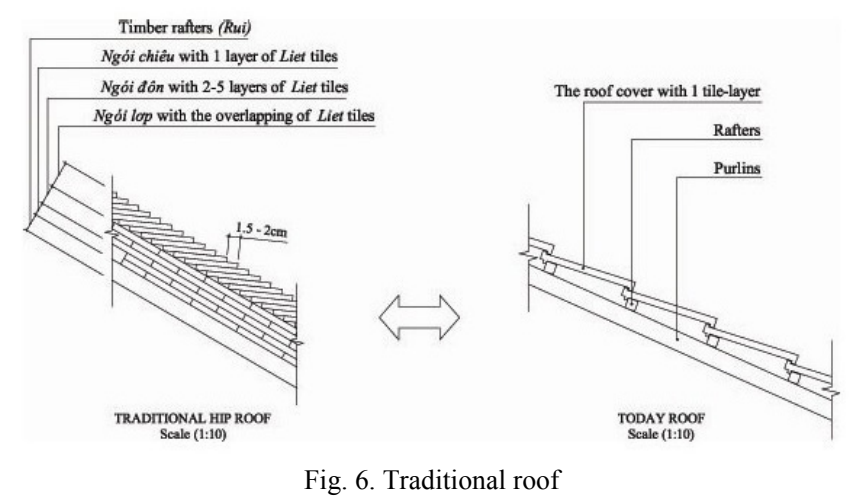

Veranda and Roof Overhang: Veranda is an external of the wall of the main house. It can be said that veranda is an architectural element to connect between house inside and enviroment outside. In hot humid climate zone, veranda participates as a factor in the protection and air conditionning for the house. When hot air flow into the house through the veranda, tempreture is cool down before entering. Moreover, the hangover of veranda prevents the direct light into the house. Factly, the width of vedanda is from $1 \mathrm{~m}$ to $2 \mathrm{~m}$, the distance between eave and floor is approximate $2 \mathrm{~m}$. In Hue city, the highest sunny is from May to August, more than 200 hours each month, also the average height of the sun of above 4 months measured at noon, when the house receives the highest radiation, is always more than 80 degree then vedanda is totally coveraged by shadow. Thus, veranda is totally coveraged by shadow. If the house do not stay in good direction, it usually have larger eaves. However some house use curtain form bamboo with the same purpose. Similary, in rainny season, veranda is also preserves the rainwater splashs to inside housing.

In the other hand, veranda is a open space for communication, relaxation and pause space for person before entering or exiting the house adapt with the high collectivism of Vietnamese culture. 
Ventilated Parts: If not properly ventilated, the roof after receive thermal from radiation would radiate that back into the house through the ceiling. By installing khu di like vents, they are two rectangle hold for air circulation on the west and east wall, under eaves, they work as an inlet-outlet part to airflow underneath the roof. The airflow goes from inlet vent to outlet vent to cool down the heat between roof and ceiling. Thanks to this system, a part of heat escape and temperature reduce indoor during the summer months. Also, resolve the problems associated with condensation, termites caused by moisture.

Main house use ban khoa doors with yin-yang mullion for ventilation. Although the low elevation house still stays cool in summer.

Ram like an insulation panel under the roof, to separate the radiation with space using under the roof. Addition, this is a small storey to keep foods or remaining place for family during the flood days, it can be seen very adaptive with climate environment of Hue city (Fig.7). The separation of main house and outhouse is a ventilation feature. The outhouse is always located on the end of the wind because outhouse includes kitchen and toilet. With this condition, outhouse always keeps dry and avoids the some smell effect from outhouse to main house.

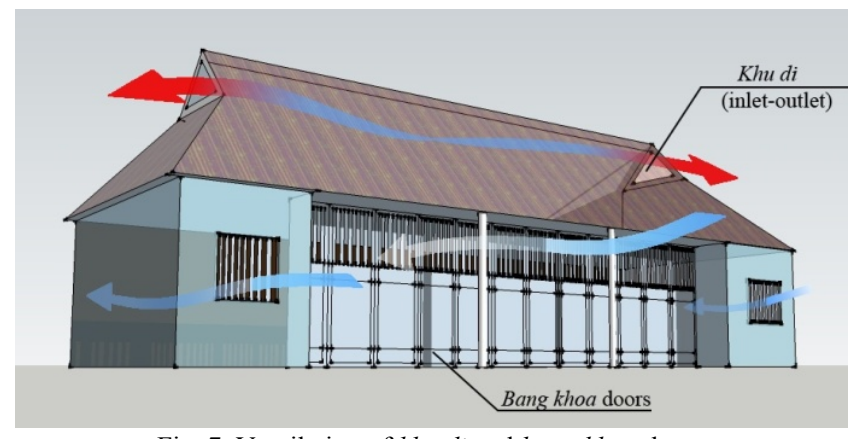

Fig. 7. Ventilation of khu di and bang khoa doors

\section{MATERIAL}

Timber is used popular for hot humid areas. HTGH is also used timber for frame structure, frame of roof, windows, doors, and walls. With high humidity in Hue city, using timber is one of effective material and creates many benefits. When the humidity is low, the evaporation of water inside timber will provide moisture to environment. On the contrary, when the humidity is high, timber absorb water from outside. The main component of wood is cellulose (40-46\% with type of tree with big leaf in tropic area); it is an insulated element, so that wooden house prevents cold in winters and hot in summers from external wall. Inside wood always has water; this is an environment to conduct heat. Therefore using dry wood is better than wet wood. Wood is dried by natural way. This measure reduces the moisture of timber, prevent decay, increase intensity, reduce the size, and form change during using. Besides that, unlike concrete and other masonry materials, timber is strong in the relation to its weight, more easily and cheaply handled and transported, and works well with simple hand tools. Properly constructed timber buildings will withstand the pressure of storm wind, being lightweight and resilient [8]. HTGH often use local wood such as jackfruit wood (anisoptera scaphula), hopea pierrei, which is grown by local habitants.

However, the disadvantage of timber is attack easily by fungus, termites, and fire. Following the oral history, the ancient people used varnish without chemical elements, it is totally different with the varnish product in the factory with the chemical elements, they soluble shellac in alcohol and use that liquid to paint timber. Shellac is a reddish resin take from secretion of Kerria lacca (Kerr. 1782) insect after processing [9]. It can protect the timber away termites and help the surface more gloss. All timber breaks down eventually. This can usually happen to either through oxidization caused by oxygen in the air, or through reaction with microorganisms, which attack the proteins and therefore the sugars. The methods of deterioration usually work together. Timber that is submerged in water is more durable because of the lower amount of oxygen, in swamps timber a lie for thousands of years without deteriorating. Therefore, to keep the wood they put under the water. Thus, in ancient time, to keeping wood for a long time, people put them under the lake or river. They just bring them up when they want to use. Wall uses bricks and traditional mortar, which is mixed paper and sugarcane. Floor often cover by many layers of soil add lime and ash to against termites, moisture. After that, with some family, they cover the last layer by bricks and glazed bricks.

\section{CONCLUSION}

If architecture is considered as a part of nature, then the building must achieve the harmony with the ecological environment. In this paper, the features of Hue traditional garden house are introduced and prove the environment adaptive of it. As a result, this research provides a data for traditional architecture application for contemporary house.

The following strategies should be considered:

1) Site selection has e a great influence to the house's characters. The best orientation for ho $t$ humid climate housing is north south. The main façade face south to catch the breeze from south in summer and avoid wind in winter.

2) Trees plant around the house with different height in order to create different pressure control flow and wind velocity. Besides that, the vegetation improves microclimate by reducing heat radiation and support shade. It also depends on kind of tree choice direction and altitude of sun.

3) Water body should locate at the advantage wind direction such as south due to cool by evaporation.

4) House in hot humid climate usually has elongated, extending along east west. The wall in west and east is usually solid to avoid radiation. Main house of HTGH in an evident to see it can extend the length easily.

5) Thick roof with thermal insulation material like clay and slope 30 degrees would be easy for reduction heat radiation and rainwater drainage.

6) Space underneath roof should have vents for wind transferring to avoid termite wood with high moisture condition.

7) Veranda is a very important factor for house in hot humid zone. Effective shade depends on the wide of 
veranda. It is also the thermal mass into the house.

8) Wide eaves keep the sun from attacking wall or window directly; also avoid the precipitation fall in wall.

9) A solution for the house with timber structure in flooding area is putting the columns on the rock mass. The columns raised way protects the timber away ground moisture and subterranean termites.

10) Yin-yang door design creates semi-closed space; it is a good condition for ventilation. Air is always clean and flow to avoid pollution and humidity.

As a result, this research provides a data for traditional architecture application in modern house. However, HTGH also have some limitation for daily life. Therefore, it is necessary changing to adaptive with the life nowadays while maintaining the traditional features.

\section{REFERENCES}

[1] V. Olgyay, Design with climate, bioclimatic approach to architecture regionalism, Princeton, New Jersey, 1962, pp.52.

[2] T. T. Hue, "The climatic conditions and hydrological of Thua Thien Hue province," Department of Science and Technology, 2004.

[3] M. Felix. L' actinometre et l'orientation des rue et des façade. La technique Sanitaire et munincipale, March, pp. 60-67; April, pp. 83-90; May, pp. 98-105; June, 1931, pp. 126-131.

[4] Central architecture research center, Project of traditional house survey in Kim Long, Hue, 2004.

[5] V. Olgyay, Design with climate, bioclimatic approach to architecture regionalism, Princeton, New Jersey, 1962, p.74.

[6] Department of Local Government, Planning, Sport, and Recreation, Queensland, "Report of workshop on Energy efficient house design in tropical Queensland," Townsville, February, 2005.
[7] H. Hideaki, Characteristics of design methods in central, Vietnam, March, 2010.

[8] J. P. R. Falconer, "Design and of tropical timber housing," 1971.

[9] Vietnam red data book-animal part, pp.389.

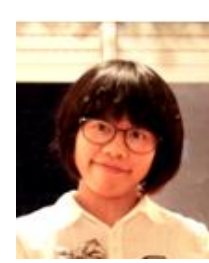

Le Ngoc Van Anh was born in Hue city, Vietnam, She graduated in Architecture Department, Hue University of science, Vietnam in "Architecture of the Construction" major (2008). She is architect; from August 2008 to December 2009 she was a teaching assistant in Architecture Department, Hue University of science. Since 2010, she is a PhD student at Department of Construction Civil Engineering and Architecture, Polytechnic University of Marche in Ancona, Italy. Her research work focus on architecture strategies for housing in hot humid climate and low-cost housing. She also collaborates to the teaching activity of "Architecture composition III" at Faculty of Engineering at Polytechnic University of Marche.

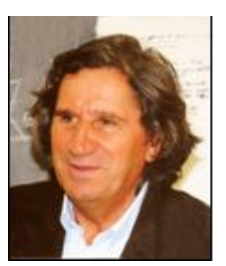

Fausto Pugnaloni was born in Italy. He is architect, full professor of Architectural Design since 1994 at the Polytechnic University of Marche. He was Ex-Dean of the Department of Architecture Survey, Drawing, Urban Planning and History at the Faculty of Engineering, Ex-Dean of School of Architecture and Building Engineering at the Faculty of Engineering at the Polytechnic University of Marche and deputy rector for International Relations of Polytechnic University of Marche in Ancona, Italy. He is full professor at the Beijing University of Civil Engineering and Architecture. He organized two workshops E-arcom, Technologies to communicate architecture. He organized conventions about conservation and exploitation of historical cities and sustainable urban planning. With UNIADRION (Telematic University of the Adriatic Ionian Basin) he works and studies about architecture and economy of the Adriatic coast. 